\title{
Correction to: Intelligent monitoring of multi-axis robots for online diagnostics of unknown arm deviations
}

\author{
Moncef Soualhi ${ }^{1,2}$ (1) $\cdot$ Khanh T. P. Nguyen ${ }^{2} \cdot$ Kamal Medjaher $^{2} \cdot$ Denis Lebel $^{3} \cdot$ David Cazaban $^{3}$ \\ Published online: 11 February 2022 \\ (c) Springer Science+Business Media, LLC, part of Springer Nature 2022
}

\section{Correction to: Journal of Intelligent Manufacturing https://doi.org/10.1007/ s10845-021-01882-0}

The original version of this article unfortunately contained a mistake. The author name 'Kamal Medjaher' has been set incorrectly as 'Kamal Medjahe'. The author name has now been corrected.

The original article has been corrected.

Publisher's Note Springer Nature remains neutral with regard to jurisdictional claims in published maps and institutional affiliations.

The original article can be found online at https://doi.org/10.1007/ s10845-021-01882-0.

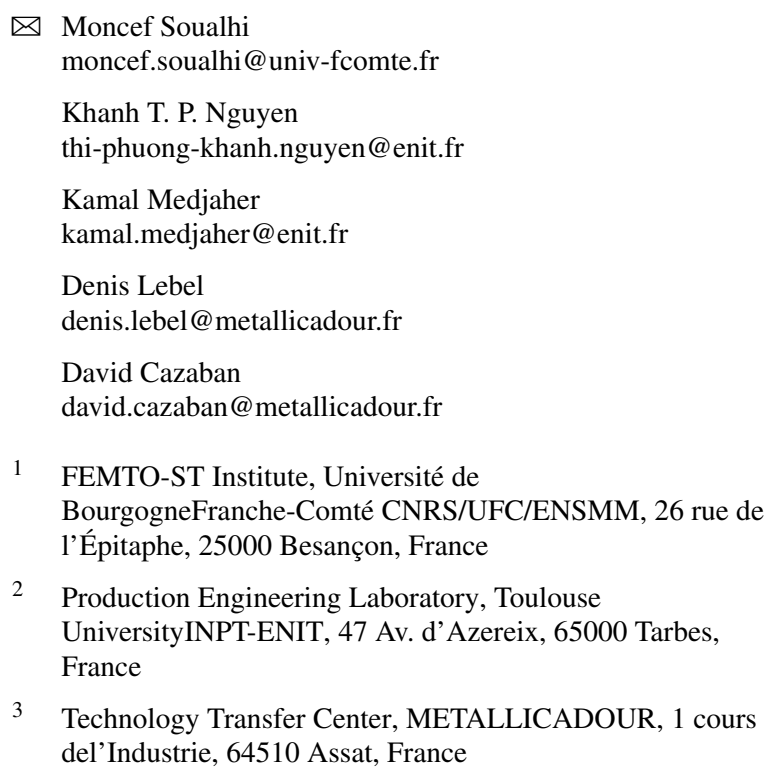

2 Production Engineering Laboratory, Toulouse UniversityINPT-ENIT, 47 Av. d'Azereix, 65000 Tarbes, 